\title{
Copper Accumulation and Distribution in Two Arboreal Species of the Atlantic Forest
}

\author{
Alessandro Reinaldo Zabotto ${ }^{1}$ (D), Wellma Santana França ${ }^{1}$ (D), \\ Marisa Domingos $^{1}$ (D), Mirian Cilene Spasiani Rinaldi ${ }^{1}$ (D), Shoey Kanashiro ${ }^{1}$ (D), \\ Mauricio Lamano Ferreira ${ }^{2}$ (D), Armando Reis Tavares ${ }^{1}$ (D) \\ ${ }^{1}$ Instituto de Botânica de São Paulo, São Paulo/SP, Brasil \\ ${ }^{2}$ Centro Universitário Adventista de São Paulo - UNASP, São Paulo/SP, Brasil
}

\begin{abstract}
This study aimed to evaluate the accumulation and distribution of copper $(\mathrm{Cu})$ in the pioneer tree Schinus terebinthifolius R. (aroeira) and non-pioneer tree Eugenia uniflora L. (pitanga) submitted to different concentrations of copper. The plants received $40 \mathrm{~mL}$ of Hoagland \& Arnon (1950) n. 1 nutrient solution modified with $0.00032,0.0032,0.032$ and $0.32 \mathrm{mM} \mathrm{Cu}^{2+}$ applied to the soil. We analyzed biomass, biometry and $\mathrm{Cu}$ contents in plants and the concentration of $\mathrm{Cu}$ in soil. $\mathrm{Cu}$ concentration in the soil contaminated with $0.32 \mathrm{mM} \mathrm{Cu}^{2+}$ was higher than other treatments. Neither species showed characteristics of plant phytotoxicity. However, the two species did exhibit different physiological responses to $\mathrm{Cu}$; $S$. terebinthifolius accumulated the metal only in roots, while E. uniflora accumulated $\mathrm{Cu}$ in roots and leaves. The highest $\mathrm{Cu}$ concentration in soil was observed in the treatment with $0.32 \mathrm{mM} \mathrm{Cu}^{2+}$. Outstanding to foliar accumulation, E. uniflora could be used for biomonitoring.
\end{abstract}

Keywords: heavy metal, contamination, mineral nutrition, phytotoxicity. 


\section{INTRODUCTION}

Copper $(\mathrm{Cu})$ is an essential micronutrient for plants, occurring naturally in soil; however, high concentrations of $\mathrm{Cu}$ can affect all components of the environment (Chaves et al., 2010). Soil contamination in areas adjacent to mining operations, as well as extensive use of fungicides in agriculture, liquid manure (mainly from pigs), sewage sludge, atmospheric deposition, and particles from car brakes has created $\mathrm{Cu}$ toxicity problems in some regions (Panagos et al., 2018). Soils in urban areas may also contain high and toxic concentrations of $\mathrm{Cu}$ from anthropogenic activities, such as traffic and industrial emissions (Vince et al., 2014).

Precipitation reactions, adsorption on mineral particle surfaces and complexation by humic substances are the main forms of $\mathrm{Cu}$ retention in soil (Khan \& Scullion, 2000). Cu distribution in soils is influenced by $\mathrm{pH}$, soil texture, organic components, microbial activity and soil temperature, all factors that influence the availability, mobility and solubility of $\mathrm{Cu}$ in soil and plants (Rodrigues et al., 2012; Argyraki et al., 2018). The availability of $\mathrm{Cu}$ in soils depends on many physicochemical processes, such as dissolution, complexation, relocation, precipitation and absorption by microbiota (Kabata-Pendias \& Pendias, 2011). The Quality Reference Value (QRV) is the concentration of a determined substance in the soil that defines a soil as clean (Carvalho et al., 2018). CETESB (São Paulo State Environmental Sanitary Technology Company, Brazil) established $35 \mathrm{mg} \mathrm{kg}^{-1}$ as the QRV value for $\mathrm{Cu}$ in soil for São Paulo State (CETESB, 2014); which, sets the limit for potential modification in the natural quality of the soil.

$\mathrm{Cu}$ is an essential nutrient for plants that plays key roles in photosynthesis, respiration, carbon and nitrogen metabolism and protection against oxidative stress (Dal Corso et al., 2014). The element is usually retained in roots and is poorly transported over the aboveground part of the plants (Ivanova et al., 2010). Available $\mathrm{Cu}$ contents in soil above $60 \mathrm{mg} \mathrm{kg}^{-1}$ for São Paulo State, Brazil (CETESB, 2014) and $140 \mathrm{mg} \mathrm{Kg}^{-1}$ for European Community (CEC, 1986) and, $20 \mathrm{mg} \mathrm{kg}^{-1}$ in whole plant shoots are considered critical, affecting root elongation, changes in membrane permeability, inhibition of electron transport in photosynthesis, immobilization of the element on cell walls and vacuoles, and chlorosis (Kabata-Pendias \& Pendias, 2011).

Urban forests impact metropolitan water, heat, carbon and pollution cycles (Livesley et al., 2016). Fontes do Ipiranga State Park (PEFI) is an urban forest within the Atlantic Forest biome that is surrounded by an urban environment (Petri et al., 2018). PEFI is influenced by the pollution produced within the urban area due to traffic emissions, industrial emissions, and sewage, among other pollutants, with different degrees of eutrophication (Schoenlein-Crusius et al., 2009). The present study aimed to evaluate the accumulation and distribution of $\mathrm{Cu}$ in leaves, stems and roots of Schinus terebinthifolius $R$. (native from PEFI and a pioneer species) and Eugenia uniflora L. (introduced to PEFI and a non-pioneer species) submitted to different concentrations of $\mathrm{Cu}$ applied to the soil.

\section{MATERIAL AND METHODS}

The experiment was conducted in a greenhouse at São Paulo, SP. Plants of the pioneer species S. terebinthifolius (7.91 g fresh leaf mass, $5.45 \mathrm{~g}$ fresh stem mass, $3.58 \mathrm{~g}$ fresh root mass, $2.29 \mathrm{~g}$ dry leaf mass, $2.21 \mathrm{~g}$ dry stem mass and $0.99 \mathrm{~g}$ dry root mass) and non-pioneer E. uniflora (6.26 g fresh leaf mass, $4.10 \mathrm{~g}$ fresh stem mass, $5.75 \mathrm{~g}$ fresh root mass, $2.86 \mathrm{~g}$ dry leaf mass, $2.09 \mathrm{~g}$ dry stem mass and $2.35 \mathrm{~g}$ dry root mass) approximately six months of age in each case were obtained from a commercial nursery. The plants were transplanted to $1.7 \mathrm{~L}$ pots with dystrophic Red-Yellow Latosol (LVA) soil (EMBRAPA, 2013) as substrate (Table 1).

The treatments consisted of $40 \mathrm{~mL} \mathrm{HA} \mathrm{n.} 1$ solution (Hoagland \& Arnon, 1950), modified with concentrations of 0.00032 (HA standard concentration for $\mathrm{Cu}$ ), 0.0032, 0.032 (CETESB recommendation for underground water $=0.0315 \mathrm{mM} \mathrm{Cu}$; CETESB, 2014) and $0.32 \mathrm{mM} \mathrm{Cu}^{2+}$, using $\mathrm{CuSO}_{4} .5 \mathrm{H}_{2} \mathrm{O}$ as a $\mathrm{Cu}$ source and applied twice a week. Salt solutions were ionically balanced, maintaining macronutrients concentrations constant in all treatments (Table 2). The $\mathrm{pH}$ of the solutions was adjusted to 5.8. The plants received irrigation by sprinklers on days alternating with the application of the nutrient solution.

After 10 months of experimentation, the biometric measurements included plant height and stem diameter 
Table 1. Soil analysis of the dystrophic Red-Yellow Latosol used in the experiment collected at $0-20 \mathrm{~cm}$ depthin PEFI.

\begin{tabular}{|c|c|c|c|c|c|c|c|c|c|c|c|c|c|c|c|c|}
\hline pH & M. & $\mathbf{P}_{\text {res }}$ & $\mathbf{A l}^{3+}$ & $\mathbf{H}^{+} \mathbf{A l}$ & K & $\mathrm{Ca}$ & Mg & SB & C.E.C. & & S & B & $\mathrm{Cu}$ & $\mathrm{Fe}$ & Mn & $\mathrm{Zn}$ \\
\hline $\mathrm{CaCl}_{2}$ & $\mathrm{~g} \mathrm{dm}^{-3}$ & $\mathrm{mg} \mathrm{dm}^{-3}$ & & - & --1 & mol & $\mathrm{Im}^{-3}$ & & -- & & & & $-\mathbf{m} \xi$ & $\mathrm{Im}$ & & \\
\hline 3.8 & 15 & 2 & 23 & 106 & 0.2 & 4 & 1 & 5 & 111 & 5 & 106 & 0.48 & 0.5 & 44 & 0.2 & 0.6 \\
\hline
\end{tabular}

Table 2. Ionic balance of different nutrient solutions formulated from Hoagland \& Arnon's solution n.1 (1950) modified with $0.00032,0.0032,0.032$ or $0.32 \mathrm{mM} \mathrm{Cu}^{2+}$, and macronutrients $(\mathrm{N}, \mathrm{P}, \mathrm{K}, \mathrm{Ca}, \mathrm{S}$ and $\mathrm{Mg}$ ).

\begin{tabular}{|c|c|c|c|c|}
\hline \multirow{2}{*}{ Ion source } & \multicolumn{4}{|c|}{ Treatments $\left(\mathrm{mM} \mathrm{Cu}^{2+}\right)$} \\
\hline & 0.00032 & 0.0032 & 0.032 & 0.32 \\
\hline $\mathrm{NH}_{4}^{+}-\left(\mathrm{NH}_{4}\right)_{2} \mathrm{SO}_{4}$ & 1.99936 & 1.99359 & 1.93588 & 1.35880 \\
\hline $\mathrm{NO}_{3}^{-}-\mathrm{Ca}\left(\mathrm{NO}_{3}\right)_{2}$ & 3.00000 & 2.99711 & 2.96826 & 2.67972 \\
\hline $\mathrm{NH}_{4}{ }^{+}$and $\mathrm{NO}_{3}{ }_{-}^{-}-\mathrm{NH}_{4} \mathrm{NO}_{3}$ & 5.00064 & 5.00930 & 5.09586 & 5.96148 \\
\hline$\left[\mathrm{NH}_{4}^{+}\right]+\left[\mathrm{NO}_{3}^{-}\right]$ & 10 & 10 & 10 & 10 \\
\hline $\mathrm{PO}_{4}^{-}-\mathrm{KH}_{2} \mathrm{PO}_{4}$ & 2.00000 & 2.00000 & 2.00000 & 2.00000 \\
\hline$\left[\mathrm{PO}_{4}^{-}\right]$ & 2 & 2 & 2 & 2 \\
\hline $\mathrm{K}^{+}-\mathrm{KH}_{2} \mathrm{PO}_{4}$ & 2.00000 & 2.00000 & 2.00000 & 2.00000 \\
\hline $\mathrm{K}^{+}-\mathrm{KCl}$ & 10.00000 & 10.00000 & 10.00000 & 10.00000 \\
\hline$\left[\mathrm{K}^{+}\right]$ & 12 & 12 & 12 & 12 \\
\hline $\mathrm{Ca}^{2+}-\mathrm{CaCl}_{2} \cdot 2 \mathrm{H}_{2} \mathrm{O}$ & 2.00000 & 2.00289 & 2.03174 & 2.32028 \\
\hline $\mathrm{Ca}^{2+}-\mathrm{Ca}\left(\mathrm{NO}_{3}\right)_{2}$ & 3.00000 & 2.99711 & 2.96826 & 2.67972 \\
\hline$\left[\mathrm{Ca}^{2+}\right]$ & 5 & 5 & 5 & 5 \\
\hline $\mathrm{Mg}^{2+}-\mathrm{MgSO}_{4} \cdot 7 \mathrm{H}_{2} \mathrm{O}$ & 0.00032 & 0.00321 & 0.03206 & 0.32060 \\
\hline $\mathrm{Mg}^{2+}-\mathrm{MgCl}_{2} \cdot 6 \mathrm{H}_{2} \mathrm{O}$ & 0.99968 & 0.99679 & 0.96794 & 0.67940 \\
\hline$\left[\mathrm{Mg}^{2+}\right]$ & 1 & 1 & 1 & 1 \\
\hline $\mathrm{SO}_{4}{ }^{2-}-\mathrm{MgSO}_{4} \cdot 7 \mathrm{H}_{2} \mathrm{O}$ & 0.00032 & 0.00321 & 0.03206 & 0.32060 \\
\hline $\mathrm{SO}_{4}^{2-}-\left(\mathrm{NH}_{4}\right)_{2} \mathrm{SO}_{4}$ & 1.99936 & 1.99359 & 1.93588 & 1.35880 \\
\hline $\mathrm{SO}_{4}{ }^{2-}-\mathrm{CuSO}_{4} \cdot 5 \mathrm{H}_{2} \mathrm{O}$ & 0.00032 & 0.00321 & 0.03206 & 0.32060 \\
\hline$\left[\mathrm{SO}_{4}^{2-}\right]$ & 2 & 2 & 2 & 2 \\
\hline $\mathrm{Cl}^{2+}-\mathrm{KCl}$ & 10.00000 & 10.00000 & 10.00000 & 10.00000 \\
\hline $\mathrm{Cl}^{2+}-\mathrm{CaCl}_{2} \cdot 2 \mathrm{H}_{2} \mathrm{O}$ & 2.00000 & 2.00289 & 2.03174 & 2.32028 \\
\hline $\mathrm{Cl}^{2+}-\mathrm{MgCl}_{2} \cdot 6 \mathrm{H}_{2} \mathrm{O}$ & 0.99968 & 0.99679 & 0.96794 & 0.67940 \\
\hline$\left[\mathrm{Cl}^{2+}\right]$ & 13 & 13 & 13 & 13 \\
\hline $\mathrm{Cu}^{2+}-\mathrm{CuSO}_{4} \cdot 5 \mathrm{H}_{2} \mathrm{O}$ & 0.00032 & 0.00321 & 0.03206 & 0.32060 \\
\hline$\left[\mathrm{Cu}^{2+}\right]$ & 0.00032 & 0.0032 & 0.032 & 0.32 \\
\hline
\end{tabular}

at soil level. The plants were sectioned into roots, stems and leaves and weighed for fresh biomass, followed by drying in an oven with forced ventilation at $60^{\circ} \mathrm{C}$ until reaching constant weight for dry biomass. The dried leaves, stems and roots were ground to a homogeneous powder and sent to the Laboratory of Mineral Nutrition in Plants at UNESP, Botucatu, SP. The dried material was wet-digested in a nitric-perchloric acid $(4: 1 \mathrm{v} / \mathrm{v})$ solution and total concentration of $\mathrm{Cu}$ was determined (Malavolta et al., 1997) by atomic absorption spectrometry (Perkin Elmer 2380, Norwalk, USA) with inductive plasma. The $\mathrm{Cu}$ soil available content was extracted by $0.1 \mathrm{~mol} \mathrm{~L}^{-1}$ DTPA solution (Büll \& Bertani, 2001) and the extract was analyzed by atomic absorption spectrophotometry (Perkin Elmer 2380, Norwalk, USA) with inductive plasma. The Translocation Index (Ti) was determined by dividing the $\mathrm{Cu}$ concentration in stems and shoots ( $\mathrm{mg} \mathrm{kg}^{-1}$ dry mass) by the $\mathrm{Cu}$ contents in roots ( $\mathrm{mg} \mathrm{kg}^{-1}$ dry mass), as recommended by Vendruscolo et al. (2018).

The experimental design included a randomized block with 4 blocks containing 5 plants per plot, totaling 80 plants. Data were analyzed through analysis of variance (ANOVA) and means compared by the Tukey's test $(p \leq 0.05)$ using the SISVAR 5.3 statistical software. 


\section{RESULTS AND DISCUSSION}

The Cu content in soil ranged from 2.5 to $13.4 \mathrm{mgCudm}^{-3}$ in soil cultivated with S. terebinthifolius and 2.9 to $13.5 \mathrm{Cu} \mathrm{mg} \mathrm{dm}^{-3}$ in soil cultivated with E. uniflora (Figure 1). Cu accumulation in soil occurred only in the $0.32 \mathrm{mM} \mathrm{Cu}^{2+}$ treatment with $13.4 \mathrm{mg} \mathrm{Cu} \mathrm{dm}^{-3}$ in soil cultivated with S. terebinthifolius and $13.5 \mathrm{Cu} \mathrm{mg} \mathrm{dm}{ }^{-3}$ in soil cultivated with E. uniflora. Those values are lower than the CETESB concentration of intervention defined as the retention of a certain substance in the soil above that is a potential risk to human health, either direct or indirect, arises (CETESB, 2014) which is $760 \mathrm{mg} \mathrm{Cu} \mathrm{kg}^{-1}$ for $\mathrm{Cu}$ in soil; while for the U.S. and Europe, these values range from 50 to $140 \mathrm{Cu} \mathrm{mg} \mathrm{kg}$. $\mathrm{Cu}$ used for the control of fungal diseases in viticulture is still very common, and $\mathrm{Cu}$ accumulation in soils has been observed at levels as 435-690 mg Cu kg${ }^{-1}$ in the wine regions of Europe (Ruyters et al., 2013) and varied between $1,355 \pm 45$ and $1,381 \pm 31 \mathrm{mg} \mathrm{kg}^{-1}$ for LU (Lithic Udorthent) and HD (Humic Dystrudept) agricultural soils in Rio Grande do Sul State, Brazil (Nachtigall et al., 2007).

The variables height and diameter of the stem, and fresh and dry mass of leaves, stems, roots and total did not show any significant differences among the treatments for S. terebinthifolius or E. uniflora (Table 3). Tree species respond differently to soils contaminated with heavy metals. For example, species, such as Myroxylon peruiferum (cabreuva), Platypodium gonoacantha (jacaranda-branco), Piptadenia gonoachanta (pau-jacaré) and Anadenanthera peregrine (angico-vermelho), have a marked reduction in relative height improvement in soils contaminated by heavy metals (Soares et al., 2001). Eucalyptus urophylla and Eucaliptytus maculata showed

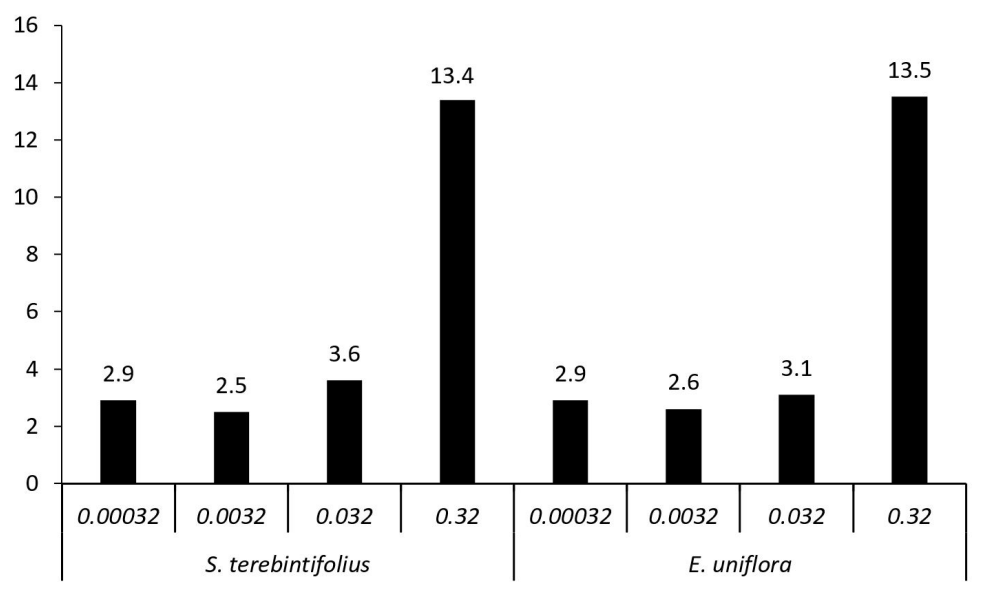

Figure 1. Cu soil-available contents $\left(\mathrm{mg} \mathrm{dm}^{-3}\right)$ in soil cultivated with S. terebinthifolius and E. uniflora treated with $0.00032,0.0032,0.032$ or $0.32 \mathrm{mM} \mathrm{Cu}^{2+}$.

Table 3. Height, stem diameter (SD), fresh leaf mass (FLM), fresh stem mass (FSM), fresh root mass (FRM), total fresh mass (TFM), dry leaf mass (DLM), dry mass of the stem (DMS), dry mass of the roots (DMR), and total dry mass (TDM) of S. terebinthifolius and E. uniflora submitted to treatments $0.00032,0.0032,0.032$ or $0.32 \mathrm{mM} \mathrm{Cu}^{2+}$.

\begin{tabular}{lllllllllllc} 
& $\begin{array}{c}{\left[\mathbf{C u}^{2+}\right]} \\
\mathbf{m M}\end{array}$ & $\begin{array}{c}\text { Height } \\
(\mathbf{m})\end{array}$ & $\begin{array}{c}\text { SD } \\
(\mathbf{m m})\end{array}$ & $\begin{array}{c}\text { FLM } \\
(\mathbf{g})\end{array}$ & $\begin{array}{c}\text { FSM } \\
(\mathbf{g})\end{array}$ & $\begin{array}{c}\text { FRM } \\
(\mathbf{g})\end{array}$ & $\begin{array}{c}\text { TFM } \\
(\mathbf{g})\end{array}$ & $\begin{array}{c}\text { DML } \\
(\mathbf{g})\end{array}$ & $\begin{array}{c}\text { DSM } \\
(\mathbf{g})\end{array}$ & $\begin{array}{c}\text { DMR } \\
(\mathbf{g})\end{array}$ & $\begin{array}{c}\text { TDM } \\
(\mathbf{g})\end{array}$ \\
& 0.00032 & $1.08 \mathrm{a}$ & $9.07 \mathrm{a}$ & $23.71 \mathrm{a}$ & $37.27 \mathrm{a}$ & $15.24 \mathrm{a}$ & $37.27 \mathrm{a}$ & $6.56 \mathrm{a}$ & $13.77 \mathrm{a}$ & $4.91 \mathrm{a}$ & $25.24 \mathrm{a}$ \\
\multirow{5}{*}{ S. terebinthifolius } & 0.0032 & $1.08 \mathrm{a}$ & $8.90 \mathrm{a}$ & $26.37 \mathrm{a}$ & $35.44 \mathrm{a}$ & $15.17 \mathrm{a}$ & $35.44 \mathrm{a}$ & $7.70 \mathrm{a}$ & $13.39 \mathrm{a}$ & $5.06 \mathrm{a}$ & $26.14 \mathrm{a}$ \\
& 0.032 & $1.16 \mathrm{a}$ & $9.29 \mathrm{a}$ & $24.20 \mathrm{a}$ & $36.02 \mathrm{a}$ & $14.17 \mathrm{a}$ & $36.02 \mathrm{a}$ & $6.80 \mathrm{a}$ & $13.32 \mathrm{a}$ & $4.80 \mathrm{a}$ & $24.92 \mathrm{a}$ \\
& 0.32 & $1.15 \mathrm{a}$ & $8.62 \mathrm{a}$ & $24.37 \mathrm{a}$ & $35.35 \mathrm{a}$ & $13.03 \mathrm{a}$ & $35.35 \mathrm{a}$ & $6.80 \mathrm{a}$ & $12.87 \mathrm{a}$ & $4.34 \mathrm{a}$ & $24.01 \mathrm{a}$ \\
& 0.00032 & $0.61 \mathrm{~A}$ & $6.62 \mathrm{~A}$ & $16.36 \mathrm{~A}$ & $15.03 \mathrm{~A}$ & $10.48 \mathrm{~A}$ & $15.03 \mathrm{~A}$ & $7.14 \mathrm{~A}$ & $7.67 \mathrm{~A}$ & $6.30 \mathrm{~A}$ & $21.11 \mathrm{~A}$ \\
\multirow{5}{*}{ E. uniflora } & 0.0032 & $0.64 \mathrm{~A}$ & $6.81 \mathrm{~A}$ & $18.04 \mathrm{~A}$ & $15.33 \mathrm{~A}$ & $14.00 \mathrm{~A}$ & $15.33 \mathrm{~A}$ & $6.92 \mathrm{~A}$ & $8.14 \mathrm{~A}$ & $7.96 \mathrm{~A}$ & $23.03 \mathrm{~A}$ \\
& 0.032 & $0.62 \mathrm{~A}$ & $6.26 \mathrm{~A}$ & $17.74 \mathrm{~A}$ & $14.75 \mathrm{~A}$ & $9.79 \mathrm{~A}$ & $14.75 \mathrm{~A}$ & $6.75 \mathrm{~A}$ & $7.20 \mathrm{~A}$ & $5.69 \mathrm{~A}$ & $19.65 \mathrm{~A}$ \\
& 0.32 & $0.60 \mathrm{~A}$ & $6.45 \mathrm{~A}$ & $16.59 \mathrm{~A}$ & $16.41 \mathrm{~A}$ & $10.88 \mathrm{~A}$ & $16.41 \mathrm{~A}$ & $6.44 \mathrm{~A}$ & $8.13 \mathrm{~A}$ & $6.58 \mathrm{~A}$ & $21.16 \mathrm{~A}$ \\
\hline
\end{tabular}

Averages followed by the same lowercase letters within a column showed that there was no significant difference between the treatments in Schinus terebinthifolius $(p \leq 0.05)$ and averages followed by the same uppercase letters within a column showed that there were no significant differences between the treatments in Eugenia uniflora $(p \leq 0.05)$. 
a decreased growth in soil concentrations higher than $0.032 \mathrm{mM} \mathrm{Cu}^{2+}$, and E. urophylla under these conditions showed aqueous spots on the leaves, later evolving to necrosis (Soares et al., 2000).

$\mathrm{Cu}$ contents in S. terebinthifolius and E. uniflora plants (Figure 2) augmented with increasing $\mathrm{Cu}$ concentration in the treatments. The $\mathrm{Cu}$ contents in S. terebinthifolius ranged from 7 to $9 \mathrm{mg} \mathrm{kg}^{-1}$ in the leaves, from 7 to $8 \mathrm{mg} \mathrm{kg}^{-1}$ in the stems and from 19 to $60 \mathrm{mg} \mathrm{kg}^{-1}$ in the roots. For E. uniflora, Cu contents ranged from 20 to $31 \mathrm{mg} \mathrm{kg}^{-1}$ in the leaves, from 9 to $10 \mathrm{mg} \mathrm{kg}^{-1}$ in the stems, and from 10 to $37 \mathrm{mg} \mathrm{kg}^{-1}$ in the roots. $\mathrm{Cu}$, as a plant micronutrient, is rapidly taken up by roots; however, this phenomenon depends on the level of metals in the soil and the physiology of each species (Dal Corso et al., 2014). Cu contents between 20 and $100 \mathrm{mg} \mathrm{kg}^{-1}$ in leaves are considered toxic for several species (Kabata-Pendias \& Pendias, 2011). S. terebinthifolius and E. uniflora showed no visible symptoms of phytotoxicity on leaves or root system as wilting and chlorosis of younger leaves, darkening of roots, and absence of secondary roots (Soares et al., 2000).

The species presented different responses to $\mathrm{Cu}$ translocation (Table 4), varying according to the increase of $\mathrm{Cu}$ concentration applied to the soil. S. terebinthifolius showed high $\mathrm{Cu}$ accumulation in roots, thus avoiding its translocation to shoots (11\% to $21 \%$ ), while E. uniflora accumulated $\mathrm{Cu}$ in roots, stem and leaves (36\% to $55 \%$ ). The restricted translocation of heavy metals to shoots is important for plant survival since $\mathrm{Cu}$ can affect biochemical pathways, altering a plant's physiological functions and damaging photosynthesis (Pätsikkä et al., 2002). Such restriction can be accomplished by apoplastic barriers as the casparian strip making selective plasma membrane transporters able to regulate elemental influx into the root symplast, efflux into the xylem and consequently shoot translocation (Ricachenevsky et al., 2018). In a sense, $S$. terebintifolius was less influenced by $\mathrm{Cu}$ concentrations because it could limit the translocation of $\mathrm{Cu}$ from roots to shoot, i.e., most likely retaining $\mathrm{Cu}$ in the roots. Plants that accumulate heavy metals in the roots, thereby limiting the translocation to the shoot system, can be considered tolerant (Verkleij \& Prast, 1989). These tolerance factors are essential if plants are to recover from areas contaminated with toxic elements owing to their ability to accumulate heavy metals in roots (Gomes et al., 2011). Accumulation of $\mathrm{Cu}$ in leaves is exceptionally rare globally and known principally from plants that grow in the Copperbelt of Central Africa, i.e., the Democratic Republic of Congo (Lange et al., 2017).

Table 4. Translocation index (\%) in S. terebinthifolius and E. uniflora submitted to treatments $0.00032,0.0032$, 0.032 or $0.32 \mathrm{mM} \mathrm{Cu}^{2+}$.

\begin{tabular}{lcc}
{$\left[\mathrm{Cu}^{2+}\right]$} & \multicolumn{2}{c}{ Translocation Index } \\
\cline { 2 - 3 }$(\mathbf{m M})$ & S. terebinthifolius & E. uniflora \\
0.00032 & 0.74 & 2.90 \\
0.0032 & 0.65 & 3.50 \\
0.032 & 0.35 & 2.56 \\
0.32 & 0.28 & 0.94 \\
\hline
\end{tabular}

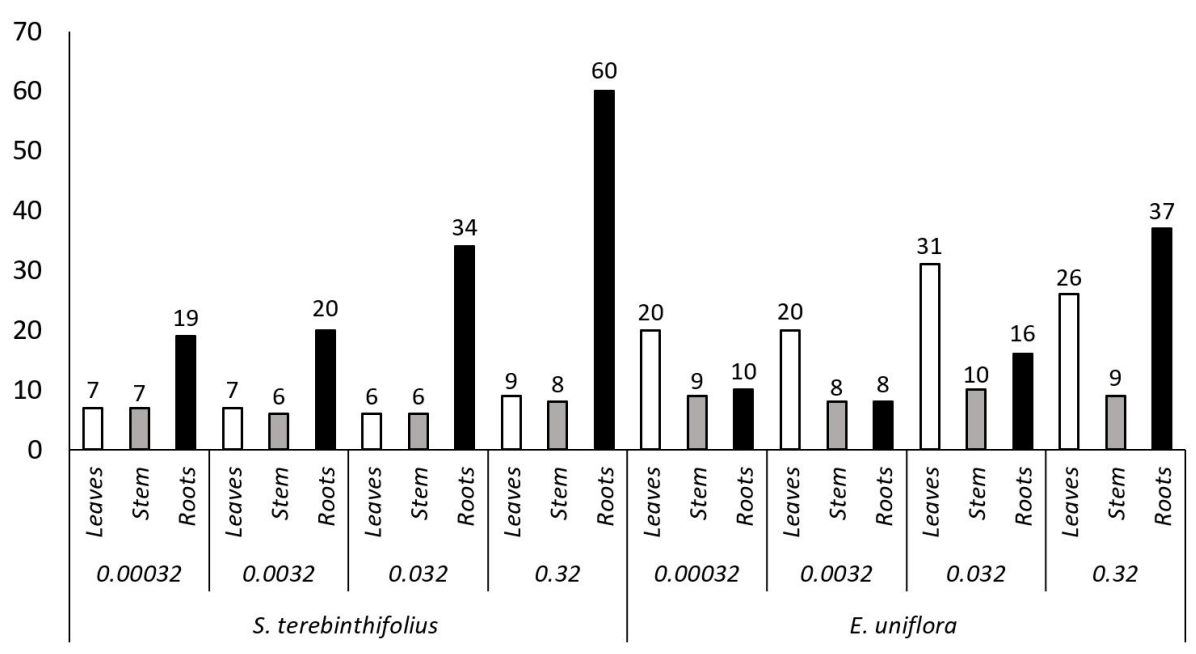

Figure 2. $\mathrm{Cu}$ contents $\left(\mathrm{mg} \mathrm{kg}^{-1}\right)$ in leaves, stems and roots of $S$. terebinthifolius and E. uniflora submitted to the treatments $0.00032,0.0032,0.032$ or $0.32 \mathrm{mM} \mathrm{Cu}^{2+}$. 
Studies that focus on the effects of heavy metals of anthropogenic origin on plants, such as those that grow in the PEFI, can bring insight into the ecology of urban forests. Our results showed that $S$. terebinthifolius and E. uniflora had no phytotoxic symptoms in roots or leaves, even at the highest treatment of $0.32 \mathrm{mM} \mathrm{Cu}^{2+}$. The levels of $\mathrm{Cu}$ found in both species do not allow us to categorize these species as hyperaccumulators, a category which requires the accumulation of $\mathrm{Cu}$ in plants to be $1,000 \mu \mathrm{g} \mathrm{g}^{-1}$ (Reeves et al., 2017). However, since can translocate and storage $\mathrm{Cu}$ in leaves E. uniflora could be used for biomonitoring of $\mathrm{Cu}$-containing areas, while $S$. terebinthifolius could be used for forest restoration in sites with soils contaminated with $\mathrm{Cu}$ based on its capacity to retain $\mathrm{Cu}$ in the roots, thereby avoiding phytotoxic effects.

\section{CONCLUSION}

Neither S. terebinthifolius nor E. uniflora showed symptoms of phytotoxicity by $\mathrm{Cu}$ at the highest dose tested $\left(0.32 \mathrm{mM} \mathrm{Cu}^{2+}\right)$. However, these two species did present very different responses to $\mathrm{Cu}$ accumulation. Specifically, S. terebinthifolius accumulated $\mathrm{Cu}$ only in roots, while E. uniflora accumulated it in roots and leaves, indicating less tolerance to translocation of this micronutrient. Because of its foliar accumulation, E. uniflora could be used for biomonitoring.

\section{ACKNOWLEDGEMENTS}

We thank PIBIC/CNPq (Conselho Nacional de Desenvolvimento Científico e Tecnológico) for awarding the fellowship to ARZ and WSF and CNPq for the productivity grant to MD (proc. 309507/2017-0).

\section{SUBMISSION STATUS}

Received: 3 apr., 2019

Accepted: 3 nov., 2019

\section{CORRESPONDENCE TO}

\section{Armando Reis Tavares}

Núcleo de Plantas Ornamentais, Instituto de Botânica - IBt, Av. Miguel Stefano, 3687, CEP 04301-902, São Paulo, SP, Brasil e-mail: atavares2005@yahoo.com.br

\section{FINANCIAL SUPPORT}

Conselho Nacional de Desenvolvimento Científico e Tecnológico (Grant/Award Number: 309507/2017-0).

\section{REFERENCES}

Argyraki A, Kelepertzis E, Botsou F, Paraskevopoulou V, Katsikis I, Trigoni M. Environmental availability of trace elements $(\mathrm{Pb}, \mathrm{Cd}, \mathrm{Zn}, \mathrm{Cu})$ in soil from urban, suburban, rural and mining areas of Attica, Hellas. Journal of Geochemical Exploration 2018; 187: 201-213. http:// dx.doi.org/10.1016/j.gexplo.2017.09.004.

Büll LT, Bertani RMA. Métodos de análise química de solo para fins de fertilidade. Botucatu: UNESP/FCA; 2001.

Carvalho F, Tavares T, Lins L. Soil contamination by a lead smelter in Brazil in the view of the local residents. International Journal of Environmental Research and Public Health 2018; 15(10): 2166. http://dx.doi.org/10.3390/ ijerph15102166. PMid:30279362.

Commission of the European Communities - CEC. Council directive on the protection of the environment, and in particular of the soil, when sewage sludge is used in agriculture. Official Journal of the European Communities 1986;181: 6-12.

Companhia Ambiental do Estado de São Paulo - CETESB. Decisão de diretoria $N^{\circ}$ 045/2014/- Aprovação dos Valores Orientadores para Solos e Águas Subterrâneas no Estado de São Paulo. São Paulo: Secretaria do meio Ambiente; 2014.

Chaves LHG, Mesquita EF, Araujo DL, França CP. Crescimento, distribuição e acúmulo de cobre e zinco em plantas de pinhão-manso. Ciência Agronômica 2010; 41(2): 167-176. http://dx.doi.org/10.1590/S180666902010000200001 .

DalCorso G, Manara A, Piasentin S, Furini A. Nutrient metal elements in plants. Metallomics 2014; 6(10): 1770-1788. http://dx.doi.org/10.1039/C4MT00173G. PMid:25144607.

Empresa Brasileira de Pesquisa Agropecuária - EMBRAPA. Sistema brasileiro de classificação de solos. 3. ed. Brasília: Embrapa Informação Tecnológica; 2013.

Gomes MP, Marques TCLLSM, Nogueira MOG, Castro EM, Soares ÂM. Ecophysiological and anatomical changes due to uptake and accumulation of heavy metal in Brachiaria decumbens. Scientia Agrícola 2011; 68(5): 566-573. http:// dx.doi.org/10.1590/S0103-90162011000500009.

Hoagland DR, Arnon DI. The water-culture method for growing plants without soil. Berkeley: California Agricultural Experiment Station; 1950.

Ivanova EM, Kholodova VP, Kuznetsov VV. Biological effects of high copper and zinc concentrations and their interaction in rapeseed plants. Russian Journal of Plant Physiology: a Comprehensive Russian Journal on Modern 
Phytophysiology 2010; 57(6): 806-814. http://dx.doi. org/10.1134/S1021443710060099.

Kabata-Pendias A, Pendias H. Trace elements in soils and plants. Boca Raton: CRC Press; 2011.

Khan M, Scullion J. Effect of soil on microbial responses to metal contamination. Environmental Pollution 2000; 110(1): 115-125. http://dx.doi.org/10.1016/S02697491(99)00288-2. PMid:15092861.

Lange B, van der Ent A, Baker AJ, Echevarria G, Mahy G, Malaisse $\mathrm{F}$ et al. Copper and cobalt accumulation in plants: a critical assessment of the current state of knowledge. The New Phytologist 2017; 213(2): 537-551. http://dx.doi. org/10.1111/nph.14175. PMid:27625303.

Livesley SJ, McPherson EG, Calfapietra C. The urban forest and ecosystem services: impacts on urban water, heat, and pollution cycles at the tree, street, and city scale. Journal of Environmental Quality 2016; 45(1): 119-124. http:// dx.doi.org/10.2134/jeq2015.11.0567. PMid:26828167.

Malavolta E, Vitti GC, Oliveira SA. Avaliação do Estado Nutricional das Plantas: princípios e aplicações. 2. ed. Piracicaba: POTAFOS; 1997.

Nachtigall GR, Nogueirol RC, Alleoni LRF, Cambri MA. Copper concentration of vineyard soils as a function of $\mathrm{pH}$ variation and addition of poultry litter. Brazilian Archives of Biology and Technology 2007; 50(6): 941-948. http://dx.doi.org/10.1590/S1516-89132007000700005.

Panagos P, Ballabio C, Lugato E, Jones A, Borrelli P, Scarpa $S$ et al. Potential sources of anthropogenic copper inputs to European agricultural soils. Sustainability 2018; 10(7): 2380. http://dx.doi.org/10.3390/su10072380.

Pätsikkä E, Kairavuo M, Šeršen F, Aro EM, Tyystjärvi E. Excess copper predisposes photosystem II to photoinhibition in vivo by outcompeting iron and causing decrease in leaf chlorophyll. Plant Physiology 2002; 129(3): 1359-1367. http://dx.doi.org/10.1104/pp.004788. PMid:12114589.

Petri L, Aragaki S, Gomes EPC. Management priorities for exotic plants in an urban Atlantic Forest reserve. Acta Botanica Brasílica 2018; 32(4): 631-641. http://dx.doi. org/10.1590/0102-33062017abb0317.

Reeves RD, Baker AJ, Jaffre T, Erskine PD, Echevarria G, Van Der Ent A. A global database for plants thathyperaccumulate metal andmetalloid trace elements. The New Phytologist 2017; 218(2): 407-411. http://dx.doi. org/10.1111/nph.14907. PMid:29139134.

Ricachenevsky FK, Araújo AT Jr, Fett JP, Sperotto RA. You shall not pass: root vacuoles as a symplastic checkpoint for metal translocation to shoots and possible application to grain nutritional quality. Frontiers of Plant Science 2018; 9: 412. http://dx.doi.org/10.3389/fpls.2018.00412. PMid:29666628.

Rodrigues SM, Cruz N, Coelho C, Henriques B, Carvalho $\mathrm{L}$, Duarte AC et al. Risk assessment for $\mathrm{Cd}, \mathrm{Cu}, \mathrm{Pb}$ and $\mathrm{Zn}$ in urban soils: chemical availability as the central concept. Environmental Pollution 2012; 183: 234-242. http://dx.doi. org/10.1016/j.envpol.2012.10.006. PMid:23194645.

Ruyters S, Salaets P, Oorts K, Smolders E. Copper toxicity in soils under established vineyards in Europe: a survey. The Science of the Total Environment 2013; 443: 470477. http://dx.doi.org/10.1016/j.scitotenv.2012.11.001. PMid:23220136.

Schoenlein-Crusius IH, Moreira CG, Bicudo DC. Aquatic Hyphomycetes in the Parque Estadual das Fontes do Ipiranga - PEFI, São Paulo, Brazil. Brazilian Journal of Botany 2009; 32(3): 411-426. http://dx.doi.org/10.1590/ S0100-84042009000300003.

Soares CRFS, Accioly AMA, Marques TCLLSM, Siqueira JO, Moreira FMS. Acúmulo e distribuição de metais pesados nas raízes, caule e folhas de mudas de árvores em solo contaminado por rejeitos de indústria de zinco. Revista Brasileira de Fisiologia Vegetal 2001; 13(3): 302-315. http://dx.doi.org/10.1590/S0103-31312001000300006.

Soares CRFS, Siqueira JO, Carvalho JD, Moreira FMS, Grazziotti PH. Crescimento e nutrição mineral de Eucalyptus maculata e Eucalyptus urophylla em solução nutritiva com concentração crescente de cobre. Revista Brasileira de Fisiologia Vegetal 2000; 12(3): 213-225. http://dx.doi. org/10.1590/S0103-31312000000300005.

Vendruscolo D, Santana NA, Souto KM, Ferreira PAA, Melo GWB, Jacques RJS. Differential behavior of the summer cover crops in the absorption and translocation of copper. Ciência Rural 2018; 48(12): e20180005. http:// dx.doi.org/10.1590/0103-8478cr20180005.

Verkleij JAC, Prast JE. Cadmium tolerance and co-tolerance in Silene vulgaris (Moench.) Garcke [= S. cucubalus (L.) Wib.]. The New Phytologist 1989; 111(4): 637-645. http:// dx.doi.org/10.1111/j.1469-8137.1989.tb02358.x.

Vince T, Szabó G, Csoma Z, Sándor G, Szabó S. The spatial distribution pattern of heavy metal concentrations in urban soils - a study of anthropogenic effects in Berehove, Ukraine. Cent. Open Geosciences 2014; 6(3): 330-343. http://dx.doi.org/10.2478/s13533-012-0179-7. 